\title{
Pengaruh Penggunaan Media Sponges Dakon Pada Materi FPB dan KPK Terhadap Hasil Belajar Siswa Kelas IV SD
}

\author{
Ayu Fitri \\ ayufitri@ubpkarawang.ac.id \\ PGSD FKIP UBP Karawang \\ The Effect of Dakon Sponges Media on Highest Common Factor (HCF) and
Lowest Common Multiple (LCM) Materials on Grade IV Learning Outcomes
}

\begin{abstract}
This study aims to determine the learning outcomes of mathematics for highest common factor (hcf) and lowest common multiple (lcm) materials the by using 'dakon' sponges media in the SDN Kondangjaya III, East Karawang District, Karawang Regency. The method used is quasi-experimental, with non equivalent control group design research. The results shows that there is a significant effect between the learning outcomes of students who use media sponges and who did not use the media. The result showed sig $=0.0000 \alpha=0.05$, indicating that the hypothesis is accepted. It can be concluded that the results of student mathematics learning in get a positive influence by using 'dakon' sponges media.
\end{abstract}

Keywords: Dakon Sponges Media, Learning Outcomes

Received date: 12 Maret 2020

Article Info

Revised date: 3 Mei 2020
Accepted date: 14 Mei 2020

\section{PENDAHULUAN}

Matematika adalah pelajaran yang penting, karena pelajaran matematika berkaitan dengan mata pelajaran lainnya. Selain matematika merupakan sslah satu pelajaran yang msuk di dalam Ujian Nasional (UN). Pendekatan yang harus digunakan dalam pembelajaran matematika haruslah sesuai dengan bahasan materi sehingga dapat mengoptimalkan hasil belajar. Salah satu mata pelajaran yang kurang diminati siswa adalah matematika. Jadi dalam proses pembelajaran diharapkan dapat membuat siswa aktif dan mampu mengembangkan kemampuan individunya dengan cara yang menyenangkan.

Berdasarkan hasil observasi yang dilakukan di SD Negeri Kondangjaya III, khususnya kelas IV. Kegiatan pembelajaran matematika di kelas IV SD Negeri Kondangjaya III sangatlah monoton, dimana metode yang digunakan selalu ceramah dan teacher centered. Adapun pada awal pembelajaran siswa tidak diberikan motivasi atau apersepsi terlebih dahulu, sehingga beberapa menit guru menjelaskan materi pelajaran siswa sudah mulai ada yang bosan, mengobrol bahkan mengantuk. Hal ini yang membuat nilai rata-rata pelajaran matematika masih rendah dari standar nilai yang ditentukan sekolah yaitu hanya mencapai nilai 4,5 . Selain itu pada proses pembelajaran guru tidak memberikan alat bantu berupa media untuk mempermudah siswa memahami materi pelajaran yang disampaikan. Sehingga siswa merasa bosan dan mengalami kesulitan pada saat pembelajaran matematika. Adapun hal-hal yang dapat dilakukan untuk mempermudah dalam proses pembelajaran bangun datar yaitu dengan menggunakan media pembelajaran agar siswa tertarik dan akan tercipta susana pembelajaran yang menyenangkan.

Dari permasalahan di atas ditemukan beberapa penyebab siswa merasa kesulitan dalam pembelajaran matematika adalah guru tidak menggunakan alat bantu atau media pembelajaran, sehingga siswa sulit membayangkan konsep FPB dan KPK dengan nyata. Oleh karena peneliti melakukan diskusi dengan guru kelas IV. Dihasilkan bahwa pembelajaran yang akan diteliti ialah pembelajaran matematika pokok bahasan FPB dan KPK, sedangkan solusi untuk mengatasi kesulitan dalam pembelajaran FPB dan KPK adalah menggunakan media sponges dakon yang berfungsi memberikan gambaran nyata cara menyelesaikan permasalahan FPB dan KPK.

Berdasarkan pemaparan di atas peneliti tertarik untuk mengungkapkan dan meneliti bagaimanakah jika dalam pembelajaran matematika menerapkan media sponges dakon sebagai bantuan untuk memvisualisasikan FPB dan KPK. Sponges dakon adalah sebuah dakon yaitu permainan 
tradisional yang berupa lubang-lubang yang diisi oleh biji-bijian. Sedangkan sponges merupakan arti dari sebuah spons, dimana media ini berupa dakon yang menyerupai karakter kartun spongebob yang digemari para anak-anak. Dengan Sponges dakon diharapkan dapat mempermudah guru untuk memahami dan membantu dalam proses belajar mengajar.

Maka, peneliti merumuskan beberapa permasalahan di atas ke dalam sebuah judul "Pengaruh Penggunaan Media Sponges Dakon pada Materi FPB dan KPK Terhadap Hasil Belajar Siswa Kelas IV Sekolah Dasar".

\section{KAJIAN PUSTAKA}

Pembelajaran matematika selalu disajikan dengan ceramah serta latihan soal. Dalam otak siswa terkadang mulai jenuh dan bosan, dengan demikian guru harus mencari inovasi yang baru untuk meningkatkan motivasi belajar siswa, ketika siswa termotivasi belajar maka hasil belajar pun akan meningkat. Salah satunya dengan menggunakan media dalam proses pembelajaran. Menurut Hudoyo (Wahyuningtyas \& Raddin, 2017:9) untuk memenuhi kebutuhan siswa, maka guru perlu memainkan beragam media dalam pembelajarannya agar siswa lebih termotivasi untuk belajar. Kata media berasal dari bahasa Lain medius yang secara harfiah berarti 'tengah', 'perantara' atau 'pengantar' (Arshad, 2011:3). Dalam bahasa arab media adalah perantara atau pengantar pesan dari pengirim kepada penerima pesan (Kustandi, 2011: 7). Criticos (Daryanto, 2010: 12) bahwa media merupakan salah satu komponen komunikasi, yaitu sebagai pembawa pesan dari komunikator menuju komunikan.

Media pembelajaran dapat dipahami sebagai segala sesuatu yang dapat menyampaikan pesan dari sumber secara terencana sehingga tercipta lingkungan belajar yang kondusif dimana penerimanya dapat melakukan proses belajar secara efektif dan efisien (Munandi, 2011:7-8). Media pembelajaran adalah alat bantu dalam proses belajar mengajar untuk merangsang pikiran, perasaan, perhatian dan kemampuan atau keterampilan pebelajar sehingga dapat mendiring terjadinya proses belajar (Tafonao, 2018:104). Media pembelajaran adalah segala sesuatu yang dapat digunakan untuk menyampaikan pesan/informasi dari materi ajar yang disusun secara terencana oleh seorang guru, sehingga tercapai tujuan pembelajaran yang diinginkan serta dapat meningkatkan hasil belajar siswa. Media yang dikemas dan disajikan dengan menarik akan membuat siswa menjadi antusias dalam belajar sehingga tujuan dari pembelajaran dapat tercapai dengan baik, media pembelajaran juga memiliki kekuatan dalam mentranfer informasi, hal ini dikarenakan pembelajaran tidak hanya dengan sekedar membaca dan mendengarkan akan tetapi juga melihat penjelasan, baik berupa gambar maupun animasi (Rosyida \& Khofifatu, 2018: 22-23).

Menurut Sanaky (2011: 4) tujuan media pembelajaran sebagai alat bantu pembelajaran, ialah mempermudah proses pembelajaran di kelas, meningkatkan efisiensi proses pembelajaran, menjaga relevansi antara materi pelajaran dengan tujuan belajar, dan membantu konsentrasi pembelajar dalam proses pembelajaran. Jadi tujuan penggunaan media pembelajaran adalah memudahkan guru dalam menyampaikan sebuah materi pelajaran, sehingga dapat mengefisiensikan proses pembelajaran dan membantu siswa dalam menerima sebuah konsep atau materi ajar. Sedangkan manfaat media pembelajaran menurut Sanjaya (dalam Witantyo, 2017: 23) ialah mengatasi keterbatasan pengalaman yang dimiliki oleh siswa, media dapat menghadirkan isi pelajaran yang tidak dapat diberikan secara langsung kepada siswa karena keterbatasan indera, ruang dan waktu, memungkinkan terjadinya interaksi langsung antara siswa dengan lingkungan, menghasilkan kesamaan pengamatan, menanamkan konsep dasar yang benar, nyata dan tepat serta dapat membangkitkan keinginan dan minat baru siswa. Penggunaan media pembelajaran sponge dakon pada pembelajaran matematika pada materi FPB dan KPK dapat memberikan pengalaman siswa secara langsung dalam mengitung FPB dan KPK, serta menanamkan konsep dasar FPB dan KPK secara nyata, dan memotivasi belajar matematika. Sejalan dengan yang diungkapkan Andrijati (2014:124) media pembelajaran matematika memiliki peranan sangat besar bagi guru yaitu untuk menyampaikan konsep-konsep dasar matematika bagi siswa

Media sponge dakon merupakan media pembelajaran berupa dakon yang berbentuk menyerupai karakter kartun spongesbob, hal ini dipilih karena usia anak sekolah dasar sangat mengemari kartun apalagi spongesbob tentu siswa sangat mengenal tokoh kartun tersebut. Sehingga diharapkan dalam proses pembelajaran siswa tertarik dan termotivasi untuk melaksanakan pembelajaran dengan baik dan menyenangkan. Dakon biasanya sering dijadikan permainan tradisional yang dilakukan oleh anak-anak kecil, lebih popular dengan permainan congklak. Bentuk dari dakon 
sendiri yaitu terdiri dari lubang-lubang yang nantinya akan diisi oleh sejenis cangkang kerang digunakan sebagai biji dakon dan jika tidak ada, kadangkala digunakan juga biji-bijian dari tumbuhtumbuhan. Permainan dakon dilakukan oleh dua orang. Dalam permainan mereka menggunakan papan yang dinamakan papan congklak dan 98 (14x7) buah biji yang dinamakan biji congklak atau buah congklak. Umumnya papan dakon tersebut dari kayu dan plastik, sedangkan bijinya terbuat dari cangkang kerang, biji-bijian, batu-batuan, kelereng atau plastik. Papan dakon terdapat 16 buah lubang yang terdiri atas 14 lubang kecil yang saling berhadapan dan 2 lubang besar di kedua sisinya.

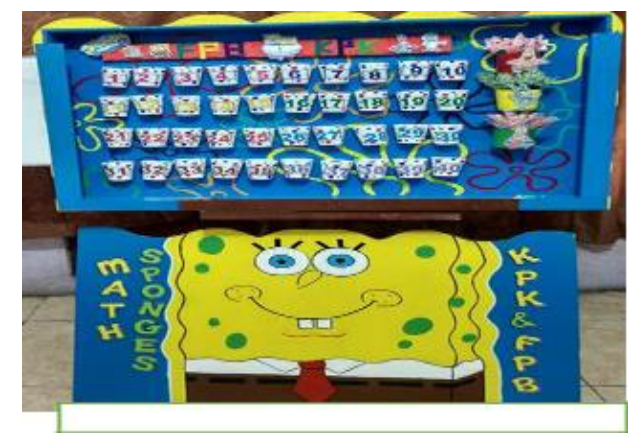

Gambar 1 Media Sponges Dakon

Alat dan Bahan yang digunakan dalam pembuatan media Sponges Dakon sangat mudah didapatkan yakni papan triplek, botol aqua, cat, kuas cat, paku, gergaji karton, dan stik es krim. Adapun cara membuat media Sponges dakon sebagai berikut:

1. Siapkan papan triplek berukuran $1 \mathrm{~m}$, potong papan triplek berbentuk kotak.

2. Berikanlah beberapa lubang pada papan triplek untuk menyimpan akua gelas dengan menggunakan bantuan bor.

3. Setelah itu buatlah pola pada papan berbentuk spongesbob.

4. Langkah berikutnya, warnai pola dengan cat minyak berwarna biru dan kuning.

5. Selanjutnya membuat stik es krim dari beberapa gambar animasi lainnya, untuk dijadikan sebagai alat untuk menghitung FPB dan KPK.

6. Buatlah tulisan untuk menghias dan memberi nama media dengan menggunakan karton.

7. Media Sponges Dakon selesai dan dapat digunakan sebagaimana mestinya. Semoga bermanfaat dan dapat membantu proses pembelajaran FPB dan KPK.

Pembelajaran menggunakan media Sponges dakon menggunakan tahapan proses belajar Bruner yakni Enaktif, Ikonik, Simbolik.. Bruner menekankan suatu proses bagaimana seseorang memilih, mempertahankan, dan mentransformasi informasi secara aktif, proses tersebut merupakan inti utama dari belajar (Fitri, 2018: 30). Teori belajar penemuan Bruner sangat menyarankan keaktifan siswa dalam proses belajar secara penuh untuk bisa menemukan Kembali berdasarkan interaksi yang dilakukannya melalui sereretan pengalman-pengalaman yang lampau (Yusri \& Sadriwanti, 2018: 149). Oleh karenanya Bruner memusatkan perhatian pada masalah apa yang dilakukan manusia terhadap informasi yang diterimanya dan apa yang dilakukan setelah menerima informasi tersebut untuk pemahaman dirinya. Adapun langkah pembelajaran media Sponges dakon sebagai berikut:

1. Tahap Enaktif

Pada tahap ini siswa belajar dengan benda konkret. Benda konkret dalam penelitian ini menggunakan media Sponges dakon. Guru memberikan apersepsi dengan mengaitkan konsep FPB dan KPK dengan kehidupan sehari-hari, kemudian menjelaskan tujuan pembelajaran menggunaan media sponges dakon. Selanjutnya siswa dibagi kedalam kelompok kemudian diberikan Lembar Kerja Siswa (LKS) yang berisikan tahapan langkah penggunaan media sponges dakon. LKS dalam tahap ini belum kepada materi FPB dan KPK baru bermain menggunakan media Sponges dakon.

2. Tahap Ikonik

Pada tahap ikonik siswa dapat mempelajari suatu pengetahuan dalam bentuk gambar atau diagram sebagai perwujudan dari suatu kegiatan yang menggunakan benda konkret. Tahap ikonik dalam penelitian ini guru meminta perwakilan kelompok untuk memaparkan hasil diskusi dengan mempraktekan menggunakan media. Kemudian guru merubah benda-benda konkret dalam media sponges dakon tersebut ke dalam konsep FPB dan KPK. 


\section{Tahap Simbolik}

Pada tahap simbolik adalah tahap dimana pengetahuan FPB dan KPK diwujudkan dalam bentuk simbolsimbol anstrak. Tahap simbolik pada penelitian ini guru meminta siswa maju kedepan serta mempraktekan contoh soal menggunakan media sponges dakon, kemudian siswa didampingi guru untuk merubah ke dalam simbol matematika. Guru menjelaslah materi FPB dan KPK. Sebelum memberikan soal evaluasi pembelajaran, siswa diberikan kesempatan untuk bertanya berkaitan materi yang tidak dipahami.

Pembelajaran media sponges dakon pada penelitian ini sejalan dengan teori Edgar Dale. Edgar Dale merupakan tokoh paling berjasa dalam perkembangan tekonologi pembelajaran moden (Warsita, 2008:11). Edgar Dale meyakini bahwa proses dan hasil belajar akan dipengaruhi oleh cara belajar mereka. Dale (1969) tertarik dengan konsep-konsep teori psikologi Bruner (1966) tentang tingkatan modus belajar yaitu pengalaman langsung (enactive), pengalaman pictoral/gambar (iconic) dan pengalaman abstrak (simbolis).Kemudian, Dale memadukan sistem klasifikasi Bruner dengan konsepnya sendiri. Konsep Bruner digambarkan oleh Arsyad dengan contoh pembelajaran tali temali. Pengalaman langsung ialah ketika siswa belajar dengan langsung membuat ikatan atau simpul dengan tali. Dengan begitu siswa belajar memahami pula makna kata simpul dipahami dengan langsung dengan membuat simpul. Sedangkan pengalaman pictoral ialah bila siswa belajar memahami kata 'simpul' melalui gambar, lukisan, foto atau film yang menunjukkan maksud kata 'simpul'. Siswa mempelajarinya melalui media berbasis visual. Sedangkan pada tingkatan simbol, siswa membaca atau mendengar penjelasan mengenai kata "simpul".

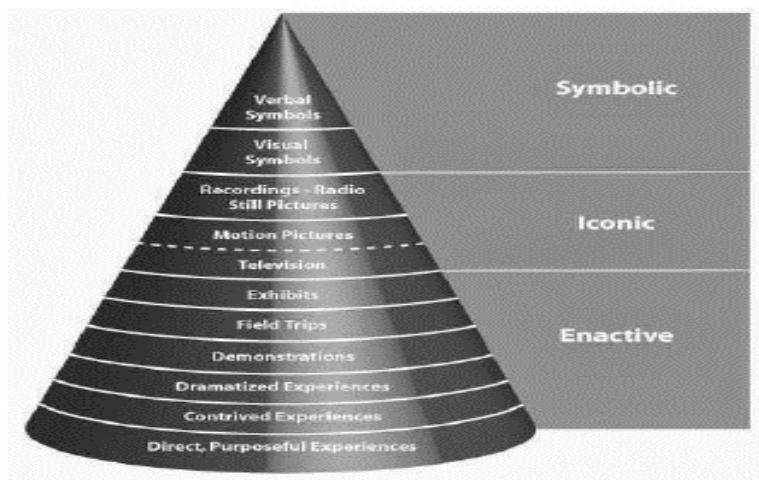

Gambar 2 Kerucut Pengalaman Edgar Dale

Dalam kerucut pengalaman itu disebutkan gambaran pengalaman dari paling konkrit (paling bawah) hingga palingabstrak (paling atas), sebagai berikut:(1) pengalaman langsung, pengalaman dengan tujuan tertentu, (2) pengalaman yang dibuat-buat, (3) pengalaman dramatis, (4) demonstrasi, (5) studi banding, (6) pameran, (7) televisi edukasi, (8) gambar bergerak, (9) rekaman radio, gambar diam, (10) simbol visual, (11) simbol verbal. Berdasarkan gambar 2 menunjukkan ada kaitannya penelitian ini dengan teori Edgar Dale. Diharapkan proses pembelajaran menggunakan media Sponges Dakon memberikan pengalaman langsung kepada siswa, sehingga siswa termotivasi dalam pembelajaran matematika. Kemudian merubah kedalam simbol matematika berupa konsep FPB dan KPK. Kegiatan proses pembelajaran ini diharapkan dapat meningkatkan hasil belajar matematika khususnya ada materi FPB dan KPK.

\section{METODE PENELITIAN}

Penelitian ini menggunakan pendekatan kuantitatif dengan jenis penelitian eksperimen semu (quasy eksperiment). Desain yang digunakan dalam penelitian ini adalah nonequivalent comparisongroup design. Tes awal (pretest) diadakan pada kedua kelompok eksperimen dan kontrol. Kemudian dilakukan uji perbedaan untuk memperoleh kondisi awal yang sama. Pada akhir perlakuan dilihat perbedaan pencapaian pretest dan posttest kelompok eksperimen dan kontrol. Hasil belajar pada masing-masing kelompok dibandingkan atau diuji perbedaannya. Jika hasil diantara kedua kelompok terdapat perbedaan, maka akan diketahui pengaruh dari perlakuan yang diberikan. 
Dalam penelitian ini yang menjadi subjeknya adalah kelas IV A dan kelas IV D semester II pada SD Negeri Kondangjaya III dengan jumlah siswa masing-masing 30 siswa. Adapun proses pengumpulan data adalah sesuai dengan tujuan peneliti, proses pengumpulan data diperoleh melalui: observasi, evaluasi dan dokumentasi. Pengolahan data dalam penelitian ini menggunakan pengolahan data kuantitatif dengan bantuan Microsoft Excel dan software SPSS.

\section{HASIL PENELITIAN DAN PEMBAHASAN}

\section{Deskripsi Data Pretest dan Postest}

Data yang diperoleh untuk mengetahui hasil belajar awal siswa pada materi FPB dan KPK dengan menggunakan program SPSS Versi 23. Adapun hasil pengolahan data pretest kedua kelas tersebut dapat dilihat pada table 1:

Tabel 1. Data Statistik Nilai Pre-test Kelas Eksperimen dan Kelas Kontrol

\begin{tabular}{lllcccc}
\hline No & Kelas & N & Nilai Max & Nilai Min & Mean & Standar Defiasi \\
\hline 1 & Eksperimen & 30 & 38 & 18 & 28,26 & 4,417 \\
\hline 2 & Kontrol & 30 & 40 & 22 & 29,93 & 4,623 \\
\hline
\end{tabular}

Berdasarkan tabel 1 bahwa yang dijadikan kelas eksperimen yakni dilihat dari mean paling rendah untuk lebih mengetahui besaran pengaruh pebelajaran menggunakan sponges dakon. Adapun hasil pengolahan data pretest kedua kelas tersebut dapat dilihat pada table 2 :

Tabel 2. Data Statistik Nilai Pre-test Kelas Eksperimen dan Kelas Kontrol

\begin{tabular}{lllcccc}
\hline No & Kelas & N & Nilai Max & Nilai Min & Mean & Standar Defiasi \\
\hline 1 & Eksperimen & 30 & 90 & 55 & 73,333 & 6,896 \\
\hline 2 & Kontrol & 30 & 65 & 40 & 49,916 & 6,554 \\
\hline
\end{tabular}

Berdasarkan tabel 2 bahwa hasil belajar menggunakan media sponges dakon pada kelas eksperimen mengalami peningkatan. Nilai tertinggi sebelum menggunakan media sponges dakon sebesar 38 meningkat menjadi 90, nilai terendah sebelum menggunakan media sponges dakon sebesar 18 meningkat menjadi 55, nilai rata-rata sebelum menggunakan media sponges dakon sebesar 28,26 meningkat menjadi 73,333 serta standar defiasi sebelum menggunakan media sponges dakon sebesar 4,417 meningkat menjadi 6,896. Hal ini menunjukan adanya pengaruh pembelajaran menggunakan media sponges dakon terhadap hasil belajar siswa.

\section{Uji Normalitas Kelas Eksperimen dan Kelas Kontrol}

Uji normalitas dilakukan untuk mengetahui sebaran data yang diperoleh dari hasil nilai pretest dan posttest berdistribusi normal atau tidak. Dengan menggunakan bantuan SPSS versi 23 dalam menghitung uji normalitas dihasilkan nilai sig. (2-tailed) pada Test yang dapat menunjukkan normal atau tidaknya sebaran data yang dihasilkan. Sebuah syarat data berdistribusi normal apabila signifikansi yang diperoleh dari hasil perhitungan lebih besar dari tingkat alpha 5\% (signifikansi >0,05). Hasil uji normalitas sebaran data pretest-posttest kemampuan berhitung dari kedua sampel penelitian dapat disajikan dalam tabel 3 berikut ini:

Tabel 3. Hasil Uji Normalitas Kelas Eskperimen dan Kontrol

\begin{tabular}{ccccc}
\hline \multirow{2}{*}{ Test } & \multirow{2}{*}{ Kelas } & \multicolumn{3}{c}{ Shapiro-Wilk } \\
\cline { 3 - 5 } & & Statistic & Df & Sig. \\
\hline Pretest & Eksperimen & 0,971 & 30 & 0,166 \\
\hline & Kontrol & 0,950 & 30 & 0,565 \\
\hline Post & Eksperimen & 0,963 & 30 & 0,360 \\
\hline & Kontrol & 0,941 & 30 & 0,094 \\
\hline
\end{tabular}

Berdasarkan tabel 3 hasil uji Normalitas pretest kelas eksperimen dan kontrol menggunakan uji Shapiro Wilk, menunjukkan bahwa nilai signifikan pre-test pada kelas eksperimen adalah 0,166 dan nilai signifikan pre-test kelas kontrol adalah 0,565. Hal ini membuktikan bahwa kedua nilai baik dari kelas eksperimen maupun kontrol lebih besar dari nilai alpha 0,05. Karena nilai signifikan kedua kelas 
lebih besar dari nilai alpha $\alpha=0,05(0,063>\alpha=0.05)$ dan $(0,082>\alpha=0.05)$, maka data kedua kelas berdistribusi normal. Sedangkan hasil uji Normalitas postest kelas eksperimen dan kontrol menggunakan uji Shapiro Wilk, menunjukkan bahwa nilai signifikan posttest pada kelas eksperimen adalah 0,360 dan nilai signifikan posttest kelas kontrol adalah 0,094. Hal ini membuktikan bahwa kedua nilai baik dari kelas eksperimen maupun kontrol lebih besar dari nilai alpha 0,05 . karena nilai signifikan kedua kelas lebih besar dari nilai alpha $\alpha=0,05(0,360>\alpha=0.05$ dan $0.094>\alpha=0.05)$, maka data kedua kelas berdistribusi normal.

\section{Uji Homogenitas Kelas Eksperimen dan Kelas Kontrol}

Uji homogenitas digunakan untuk mengetahui apakah skor Posttest kelas eksperimen dan kontrol mempunyai varians yang homogen atau tidak. Pengujian data homogenitas ini menggunakan uji Lavene's Test dengan menggunakan SPSS. Hipotesis yang digunakan sebagai berikut :

$\mathrm{H}_{0}$ : Tidak terdapat perbedaan varians skor akhir antara kelas eksperimen dan kelas kontrol

$\mathrm{H}_{1}$ : Terdapat perbedaan varians skor akhir antara kelas eksperimen dan kelas kontrol

Untuk uji Homogenitas perhitungan menggunakan SPSS Versi 23, dengan pedoman untuk mengambil kesimpulan adalah :

Jika nilai Sig. $<0,05$ maka $\mathrm{H} 0$ ditolak

Jika nilai Sig. $\geq 0,05$ maka $\mathrm{H} 0$ diterima berikut ini:

Hasil uji homogenitas skor posttest kelas eksperimen dan kelas kontrol disajikan dalam tabel 4

Tabel 4. Hasil Uji Homogenitas

Kelas Eksperimen dan Kelas Kontrol

\begin{tabular}{llll}
\hline Levene Statistic & df1 & df2 & Sig. \\
\hline 0,135 & 1 & 58 & 0,715 \\
\hline
\end{tabular}

Berdasarkan tabel 4 bahwa hasil uji homogenitas menunjukan nilai P-value sebesar 0.715 nilai tersebut lebih besar dari pada nilai signifikansi yaitu 0,05 maka H0 diterima. Dengan demikian, hasil pengujian dengan Lavene's test menggunakan SPSS tersebut memberikan kesimpulan bahwa secara signifikan tidak terdapat perbedaan varians skor akhir antara kelas eksperimen dan kelas kontrol.

\section{Uji Hipotesis}

Untuk mengetahui apakah terdapat perbedaan pada hasil belajar FPB dan KPK siswa sebelum diberikan perlakuan. Jika skor pretest kedua kelas penelitian berdistribusi normal dan variansinya homogen, maka pengujian nya dilakukan dengan uji t (Independent Sample T-Test) dengan asumsi varian homogen. Sedangkan untuk skor pretest kedua kelas penelitian berdistribusi normal tetapi tidak memiliki varians homogen, maka pengujiannya menggunakan uji t (Independen Sample T-test) dengan asumsi varians tidak homogen. Dengan hipotesis yang digunakan adalah:

- $\mathrm{H}_{\mathrm{o}}$ : Media sponges dakon tidak berpengaruh positif dan siginifkan terhadap hasil belajar pada siswa kelas IV SD Negeri Kondangjaya III.

- $\mathrm{H}_{1}$ : Media sponges dakon berpengaruh positif dan siginifkan terhadap hasil belajar pada siswa kelas IV SD Negeri Kondangjaya III.

Tabel 5. Uji-t Skor Pretest dan posttest

\begin{tabular}{cllll}
\hline Test & Kelas & Nilai Sig & Taraf Signifikan & Kesimpulan \\
\hline \multirow{2}{*}{ Pretest } & Eksperimen & \multirow{2}{*}{0,159} & 0,05 & $\mathrm{H}_{\mathrm{o}}$ diterima \\
\cline { 2 - 5 } & Kontrol & & & \\
\hline \multirow{2}{*}{ Posttest } & Eksperimen & 0,000 & 0,05 & $\mathrm{H}_{\mathrm{o}}$ ditolak \\
\cline { 2 - 4 } & Kontrol & &
\end{tabular}

Berdasarkan tabel 5 bahwa hasil uji hipotesis bahwa nilai signifikansi (2-tailed) sebesar 0,000. yang digunakan untuk pengujian perbedaan rata-rata skor akhir hasil belajar FPB dan KPK siswa yaitu dua pihak, Karena nilai sig 0,000 maka Ho ditolak Artinya, terdapat perbedaan skor akhir hasil belajar FPB dan KPK antara siswa yang menggunakan media sponges dakon dengan yang tidak menggunakan media pembelajaran. 


\section{SIMPULAN DAN SARAN}

Berdasarkan hasil penelitian dapat disimpulkan bahwa terdapat perbedaan rata-rata hasil belajar siswa materi FPB dan KPK antara kelas eksperimen yang diberi perlakuan dengan menggunakan media sponges dakon dan kelas kontrol tanpa menggunakan media pembelajaran. Nilai rata-rata posttets hasil belajar FPB dan KPK pada kelas eksperimen 73,33 sedangkan nilai rata-rata kelas kontrol 48,91. Hasil analisis data yang diperoleh dari uji-t $t_{\text {tabel }}=0,00$ dengan taraf signifikan $\alpha=0,05$ Hal ini dapat disimpulkana bahwa hasil belajar menggunakan media sponges dakon dapat berpengaruh positif terhadap hasil belajar matematika FPB dan KPK.

Adapun saran bahwa media sponge dakon dapat dijadikan sebagai alat bantu untuk mengkonkretkan dalam melaksanakan pembelajaran di dalam kelas khususnya pembelajaran matematika faktor Persekutuan Terbesar (FPB) dan Kelipatan Persekutuan Terkecil (KPK).

\section{DAFTAR PUSTAKA}

AH, Sanaky Hujair. (2011). Media Pembelajara Buku Pegangan Wajib Guru dan Dosen. Kaukaba. Yogyakarta

Andrijati, N. 2014. Penerapan Media Pembelajaran Inovatif dalam Pembelajaran Matematika Sekolah Dasar di PGSD UPP Tegal. Jurnal Penelitian Pendidikan. 31 (2).123-132.

Anitah. (2008). Strategi Pembelajaran di SD. Jakarta: Universitas Terbuka

Arikunto, S. (2010). Prosedur Penelitian. Jakarta: Rineka Jaya.

Arsyad, A. (2016). Media Pembelajaran. Jakarta. PT Raja Grafindo Persada.

Asyhar, R. (2012). Kreatif Mengembangkan Media Pembelajaran. Jakarta: Referensi

Awalia, I., Aan S. P., \& Trian P.A. (2019). Pengembangan Media Pembelajaran Animasi Powtoon pada Mata Pelajaran matematika di Kelas IV SD. Jurnal Matematika Kreatif Inovatif (Kreano). 10 (1). 49-56.

Borboa, D., Joeseph, M., Spake, D., \& Yazdaparast, A. (2017) Perceptionis and Use of Learning Management System Tools and Other Technolohies in Higher Education: a Preliminary Analysis. Journal of Learning in Higher Education, 10 (2). 17-23

Darmawan, D. (2013). Teknologi Pembelajaran. Bandung: Remaja Rosdakarya.

Daryanto. (2010). Media Pembelajaran. Yogyakarta: Gava Media.

Depdiknas. (2003). Undang-Undang Nomor 20 Tahun 2003, Sistem Pendidikan Nasional.

Dimyati, \& Mudjiono. (2009). Belajar dan Pembelajaran. Jakarta: Rineka Cipta.

Fitri, A. (2018). Belajar dan Pembelajaran Matematika di SD. Karawang: FBIS Publishing.

. (2018). Penggunaan Media Audio Visual dalam Pembelajaran IPA untuk Meningkatkan Hasil Belajar di SDN Telukjambe II. Jurnal Sekolah Dasar (JSD). 1 (3). 66-74.

Hamdani. (2011). Strategi Belajar Mengajar. Bandung: Pustaka Setia.

Heinch, R., Molenda, M., Russel, D.J., \& Smaldino, S.E. (2000). Insturctional Media adna Technologies for Learning. USA: Courier Kendallville, Inc.

Huda, M. (2016). Pembelajaran Berbasis Multimedia dan Pembelajaran Konvensional. Jurnal Penelitian, 10 (1). 125-146.

Khairiyah, U. (2019). Respon Siswa terhadap Media Dakon Matika materi KPK dan FPB pada Siswa Kelas IV di SD/MI Lamongan. Jurnal Studi Kependidikan dan Keislaman (Al-Murabbi). 5 (2). 197-204.

Lestari, D. (2014). Penerapan Teori Bruner untuk Meningkatkan Hasil Belajar Siswa pada Pembelajaran Simetri Lipat di Kelas IV SDN 02 Makmur Jaya Kabupaten Mamuju Utara. Jurnal Kreatif Tadaluko Online, 3 (2). 149-141. 
Pengaruh Penggunaan Media Sponges Dakon Pada Materi FPB dan KPK Terhadap Hasil Belajar Siswa Kelas IV SD (Ayu Fitri)

Munandi, Y. (2010). Media Pembelajaran Sebuah Pendekatan Baru. Jakarta : Gaung Persada Press.

Musfiqon. (2012). Pengembangan Media dan Sumber Pembelajaran. Jakarta: Prestasi Pustaka.

Natalia, P. (2015). Efektivitas Penggunaan Media Pembelajaran Permainan Traditional Congklak untuk Meningkatkan Kemampuan Berhitung pada Siswa Sekolah Dasar. Jurnal Ilmiah Psikologi Terapan (JIPT), 3 (2). 343-358.

Pusat Pengembangan Program Profesi. (2012). Teori Belajar dalam Pembelajaran Matematika. Jakarta: Kemendikbud.

Rosyida, F., \& Khofifatu, R.A. (2018). Pelatihan Pembuatan Media Pembelajaran dengan Program Autoplay untuk Guru SMPN 2 Balen Kecamatan Balen Kabupaten Bojonegoro. Jurnal Praksis dan Dedikasi Sosial. 1 (1). 21-28.

Sanjaya, W. (2012). Media Komunikasi Pembelajaran. Jakarta: Kencana.

Sari, P. (2019). Analisis Terhadap Kerucut Pengalaman Edgard Gale dan Keragaman Gaya Belajar untuk Memilih Media yang Tepat dalam Pembelajaran. Jurnal Manajemen Pendidikan (Mudir), 1 (1). $58-78$

Slameto. (2013). Belajar dan Faktor-faktor yang Mempengaruhi. Jakarta: Rineka.

Sudaryono. (2013). Pengembangan Instrumen Penelitian Pendidikan. Yogyakarta: Graha Ilmu

Sudijono, A. (2011). Pengantar Evaluasi Pendidikan. Jakarta: PT Raja Grafindo Persada.

Sugiono. (2015). Metode Penelitian Pendidikan. Banding: Alfabeta.

. (2010). Metode Penelitian Pendidikan Pendekatan Kuantitatif, Kualitatif, dan R\&D. Bandung: Alfabeta

Sukmadinata, N. S. (2010). Metode Penelitian Pendidikan. Bandung: PT Remaja Rosdakarya.

Sundayana, R. (2013). Media Pembelajaran Matematika untuk Guru, Calon Guru, Orang Tua, dan Para Pencinta Matematika. Bandung: Alfabeta.

Susanto. (2013). Teori Belajar dan Pembelajaran di Sekolah Dasar. Jakarta: Prenadamedia Group.

Syah, M. (2003). Psikologi Belajar. Jakarta: PT Raja Grafindo Persada.

Syahdan, St., \& Suwardi, A. 2016. The Effectivieness of The Implementation of Experience, Language, Pictorial, Symbol, and Application (ELPSA) in Mathematics Learning Based on Bruner Theory to Class VII Students at SMPN 29 1n Makassar. Jurnal Daya Matematis, 4 (2). 192-206.

Tafonao, T. (2018). Peranan Media Pembelajaran dalam Meningkatkan Minat Belajar Matematika. Jurnal Komunikasi Pendidikan, 2 (2). 103-114.

Warsita, B. (2008). Teknologi Pembelajaran. Jakarta: Rineka Cipta.

Wahyudin. (2013). Matematika Dasar Pengetahuan Bermuatan Pedagogis. Bandung: Mandiri.

Wahyuningtyas, D.T., \& Raddin, N.S. (2017). Pelatihan Media Pembelajaran Matematka Berdasarkan Kurikulum 2013 bagi Guru Sekolah Dasar di Gugus 9 Kecamatan Sukun Malang. Jurnal Dedikasi. 14 (1). 8-11.

Widoyoko, E.P. (2014). Penilaian Hasil Pembelajaran di Sekolah. Yogyakarta: Pustaka Belajar.

Yusri, A.Y. \& Sadriwanti, A. (2018). Desain Pembelajaran Kooperatif Berbasis Teori Bruner untuk Meningkatkan Kualitas Pembelajaran Matematika. Jurnal Pendidikan Matematika. 2 (2). $147-$ 158 